\title{
Bruceine D and Afatinib Combination Inhibits \\ Ovarian Cancer Cells Proliferation and Migration Through DNA Damage Repair and EGFR Pathway
}

Feng Lin

The First Affiliated Hospital of Wenzhou Medical University

Ju-fan Zhu

The First Affiliated Hospital of Wenzhou Medical University

Luo Wang

Zhengzhou University Medical College

Yuan-jun Yang

The First Affiliated Hospital of Wenzhou Medical University

Ru-ru Zheng

The First Affiliated Hospital of Wenzhou Medical University

\section{Xu Zhang}

The First Affiliated Hospital of Wenzhou Medical University

Yan Hu ( $\nabla$ huyanteach2021@163.com )

The First Affiliated Hospital of Wenzhou Medical University https://orcid.org/0000-0002-2781-1781

\section{Research Article}

Keywords: ovarian cancer, EGFR, DNA damage, anti-proliferation, anti-migration.

Posted Date: November 11th, 2021

DOI: https://doi.org/10.21203/rs.3.rs-1052397/v1

License: (9) This work is licensed under a Creative Commons Attribution 4.0 International License.

Read Full License 


\section{Abstract}

Owing to the high rates of relapse and migration, ovarian cancer has been recognized as the most lethal gynecological malignancy worldwide. The activity of the EGFR signaling pathway is frequently associated with ovarian cancer cell proliferation and migration. Despite this knowledge, inhibition of EGFR signaling in ovarian cancer patients failed to achieve satisfactory therapeutic effects. In this study, we identified that Bruceine D and EGFR inhibitor, afatinib, combination resulted in synergistic antiovarian cancer effects. The results indicated that compared with one of both drugs alone, the combination of Bruceine D and afatinib slowed the DNA replication rate, inhibition of cell viability, and proliferation and clone formation. This resulted in cell cycle arrest and cell apoptosis. In addition, the combination of Bruceine $\mathrm{D}$ and afatinib possessed a stronger ability to inhibit the ovarian cancer cell adhesion and migration than treatment with Bruceine D or afatinib alone. Mechanistically, the combined treatment triggered intense DNA damage, suppressed DNA damage repair, and enhanced the inhibition of the EGFR pathway. These results demonstrated that compared with each pathway inhibition, combined blocking of both DNA damage repair and the EGFR pathway appears to more effective against ovarian cancer treatment. The results support the potential of Bruceine $D$ and afatinib combination as a therapeutic strategy for ovarian cancer patients.

\section{Introduction}

Ovarian cancer $(\mathrm{OC})$ is the seventh most common cancer among women worldwide and the most lethal gynecological malignancy (1). Despite this, great efforts are still made to advance the treatment of ovarian cancer, even though the prognosis of this condition is poor and its five-year survival rate is only $46 \%(2,3)$. Chemotherapy, which typically consists of platinum and taxol based therapy, is the general treatment for OC; however, most women relapse 6-12 months after the last treatment and develop resistance (4). This highlights the urgent need for the development of the new therapeutic strategy. This highlights the urgent need for a new therapeutic strategy.

The human epidermal growth factor receptor (EGFR), which is a member of ErbB family of receptor tyrosine kinase, can regulate cell proliferation, angiogenesis, and migration via activated downstream pathways (5). The EGFR pathway is amplified in most cancer cells and has previously been reported to be associated with resistance to chemotherapy and radiotherapy (6). Small molecules that targeted EGFR have achieved significant efficacy in some cancer patients (7), for example, in the setting of lung cancer with known EGFR mutations (8). Recent studies have revealed that EGFR is overexpressed in nearly $70 \%$ of $\mathrm{OC}$ and had a positive correlation with poor prognosis $(9,10)$. This indicates that EGFR might be a potentially valuable target for the treatment of OC; however, clinical trials with several different EGFR inhibitors have shown only modest activity in the setting of OC. In addition, cells would develop resistance quickly during treatment with an EGFR inhibitor (11). On a more promising note, an EGFR inhibitor (e.g., afatinib) was able to sensitize the anticancer activity of chemotherapeutic drugs in some cancer cells, such as in the setting of pancreatic, colorectal, breast, and non-small cell lung cancers (12). 
Together, these data suggest that the combination of EGFR inhibitor and a chemotherapeutic drug might be an extremely valuable strategy for the treatment of OC.

Natural compounds have been considered as an important source of anticancer drugs (13). Bruceine D (BD), which is one of the active components of Brucea javanica, is widely used to treat cancer in China (14). In the setting of the clinic, BD showed vital anticancer activity in lung cancer (15),hepatocellular carcinoma(16), human chronic myeloid leukemia(17) and pancreatic cancer(18). In addition, the anticancer mechanisms of BD have been studied in the setting of these cancers, such as the idea that BD-mediated pancreatic cell death may be due to NF-kB inhibition and p38-MAPK pathway activation (19). BD also inhibits hepatocellular carcinoma growth in vivo and in vitro by reducing Wnt translational activity (20); however, little has been reported about the anticancer effects of BD in the setting of OC, so these mechanisms remain unclear.

In the current study, we investigated the anticancer effect of BD and afatinib combination in OC cells and explored the underlying antitumor pharmacological mechanisms. We demonstrated that compared to BD and/or afatinib treatment alone, the combination of $\mathrm{BD}$ and afatinib had a stronger ability to inhibit $\mathrm{OC}$ cell proliferation and migration. The possible mechanisms of BD and afatinib were discussed as well. This study might provide a strategy for $\mathrm{OC}$ treatment.

\section{Materials And Methods Cell culture}

The ovarian cancer cell line A2780, CP70 and human normal lung line MRC-5 were purchased from Cell Resource Center of Peking Union Medical College. The cells were cultured at $37^{\circ} \mathrm{C}$ under $5 \% \mathrm{CO}_{2}$, simultaneously maintained in DMEM/RPMI 1640/MEM (Gibco, USA), supplemented with $10 \%$ FBS (Gibco, USA) and 1\% penicillin-streptomycin.

\section{Drugs Administrations}

Bruceine D (CAS:21499-66-1) and afatinib (CAS: 439081-18-2) were purchased from Shanghai Yuanye Biotechnology Company and were dissolved in dimethyl sulfoxide (DMSO) to appropriate concentrations. The same amount of DMSO was also given to the control group to eliminate error. Bruceine $D$ and afatinib were added to the $\mathrm{A} 2780$ and $\mathrm{CP} 70$ cells at the same time for $48 \mathrm{~h}$ for all experiments.

\section{Cell Viability Assay}

Cell viability was detected by 3-(4, 5-dimethylthiadiazole-2-yl)-2, 5-diphenyltetrazolium bromide (MTT) (21). Cells (3,000 cells/well in 96-well plates) were cultivated for $48 \mathrm{~h}$ and then MTT was added with the final concentration of $0.5 \mathrm{mg} / \mathrm{mL}$ for $4 \mathrm{~h}$ in $37^{\circ} \mathrm{C}$. The reaction product formazan was dissolved in DMSO 
after removing the medium. Cell viability was calculated by reading absorbance at $490 \mathrm{~nm}$ using an automated Thermo Fisher Multiskan FC microplate. The results are showed as the mean \pm standard deviation of three measurements $(n=3)$.

\section{Long-term Proliferation Studies}

A2780 and CP70 cells $\left(2.0 \times 10^{5}\right.$ cells/well in 6-well plates) were added in BD or afatinib or the combination of $\mathrm{BD}$ and afatinib for $48 \mathrm{~h}$. During proliferation, the number of cells in each well was counted by the cell counter. Subsequently, the cells $\left(2.0 \times 10^{5}\right)$ were moved into a 6 -well plate to continue to cultivate and then count the cell numbers of each group until the cells were less than $2.0 \times 10^{5} .2^{\mathrm{PDs}}$ $=\mathrm{M} / \mathrm{N}$ (PDs: population doublings, $\mathrm{M}$ : number of every count cells, $\mathrm{N}=$ number of cells implanted) (22).

\section{Western Blot}

Western blot

A2780 and CP70 cells $\left(2.0 \times 10^{5}\right.$ cells/well in 6-well plates) were added in BD or afatinib or the combination of BD and afatinib for $48 \mathrm{~h}$. After that, the cells were dissolved and boiled for 10 minutes as samples. The proteins were separated via SDS-PAGE, moved to PVDF membranes and incubated with related primary antibodies at $4^{\circ} \mathrm{C}$ overnight. The next day the membranes were incubated with secondary antibodies for $1.5 \mathrm{~h}$ at room temperature. The results were showed by Image Lab ${ }^{\mathrm{TM}}$ Software on a ChemiDoc XRS+ (BioRad, USA) (23).

\section{Colony Formation}

A2780, CP70 and MRC-5 (3000 cells/well in 12-well plates) were added in BD or afatinib or the combination of $\mathrm{BD}$ and afatinib for $48 \mathrm{~h}$. When the colonies had grown completely in the control group, every well of plates were cleaned by PBS, then the cells were fixed with $4 \%$ paraformaldehyde and subsequently stained with crystal violet. Colonies in each plate were photographed under a light microscope. Ultimately the crystals were dissolved using $500 \mu \mathrm{L}$ acetic acid $(33 \%)$ and the results were calculated by reading absorbance at $560 \mathrm{~nm}$ by using an automated Thermo Fisher Multiskan FC microplate (24).

\section{Edu Staining Assay}

A2780 and CP70 cells (5.0×104 cells/well in 12-well plates with coverslips) were added in BD or afatinib or the combination of BD and afatinib for $48 \mathrm{~h}$. The EdU staining Proliferation kit (Beyotime, China) was used to examine the cells. Ultimately, using Nikon Fluorescence Microscope to observe the cells. 


\section{Cell Cycle Distribution Analysis}

A2780 and CP70 cells $\left(2.0 \times 10^{5}\right.$ cells/well in 6-well plates) were added in BD or afatinib or the combination of BD and afatinib for $48 \mathrm{~h}$. After that, the cells were trypsinized, washed, and stained with propidium iodide, subsequently were assessed on a flow cytometer (BD FACSCalibur, BD Biosciences) for the cell cycle distribution (21).

\section{Annexin V/pi Apoptosis Assay}

A2780 and CP70 cells $\left(2.0 \times 10^{5}\right.$ cells/well in 6-well plates) were added in BD or afatinib or the combination of BD and afatinib for 48h. Cells were collected for Anexin V/PI apoptosis assay via the protocol of the Annexin V/PI apoptosis Kit (Sigma), and then the cells were detected by a flow cytometer (BD FACSCalibur, BD Biosciences) (22).

\section{Immunofluorescence (If) Assays}

A2780 and CP70 cells $\left(5.0 \times 10^{4}\right.$ cells/well in 12-well plates with coverslips) were added in BD or afatinib or the combination of BD and afatinib for $48 \mathrm{~h}$. After that, cells were fixed with $4 \%$ paraformaldehyde and then permeabilized in $0.5 \%$ Triton X-100 for 30 minutes. Subsequently the cells were blocked with $5 \% \mathrm{GS}$ for $1 \mathrm{~h}$, incubated with primary antibody (53BP1) at $4^{\circ} \mathrm{C}$ overnight, which detected DNA damage criterion. The next day, the cells were cleaned by PBST, incubated with secondary antibody (anti-rabbit 488) for 1.5h and mounted with DAPI finally. The fluorescent images were captured by using Nikon fluorescence microscope (22).

\section{Comet Assays}

DNA damage was detected via neutral or alkaline comet assay. Firstly, A2780 and CP70 cells $\left(2.0 \times 10^{4}\right.$ cells/well in 12-well plates) were added in BD or afatinib or the combination of BD and afatinib for $48 \mathrm{~h}$. The cells were mixed with $0.5 \%$ low-melting temperature agarose and layered on slides pre-coated by $1.5 \%$ normal agarose. Then the slides were lysed in 3\% DMSO, 100mM EDTA, $10 \mathrm{mM}$ Tris (pH 8.0), $0.5 \%$ Triton X-100, 2.5 M NaCl, and 1\% N-lauroylsarcosine. After that, the cells were electrophoresed in $1 \%$ DMSO, $300 \mathrm{mM}$ sodium acetate and $100 \mathrm{mM}$ Tris- $\mathrm{HCl}$ at $1.5 \mathrm{~V} / \mathrm{cm}$, and mounted with PI solution ultimately. The slides were visualized by a Nikon fluorescence microscope and the results were analysed with CASP (24).

\section{The Calculation Of Combination Index (Ci) Of Drug Interaction}


The $\mathrm{Cl}$ of $\mathrm{BD}$ interaction with afatinib was measured via the Chou-Talalay method (24). The results were performed with the CompuSyn software, where $\mathrm{Cl}<1,=1$, and $>1$ indicate synergistic, additive, and antagonistic effects respectively.

\section{Cell Adhesion Assay}

A2780 and CP70 cells $\left(2.0 \times 10^{5}\right.$ cells/well in 6-well plates) were added in BD or afatinib or the combination of $\mathrm{BD}$ and afatinib for $48 \mathrm{~h}$. And $2.5 \mathrm{mg} / \mathrm{mL}$ human fibronectin in PBS (Millipore, $\mathrm{CA}$ ) was pre-coated in a 96 -well plate at $4^{\circ} \mathrm{C}$ overnight. After that, the cells $\left(5.0 \times 10^{4} /\right.$ well) were planted into serumfree medium and cultivated at $37^{\circ} \mathrm{C}$ for 20 minutes. Then the cells were fixed with $4 \%$ paraformaldehyde and stained with crystal violet after the medium was removed. In the end the crystals were dissolved by $100 \mu \mathrm{L}$ acetic acid (33\%) and the results were determined by reading absorbance at $560 \mathrm{~nm}$ using an automated Thermo Fisher Multiskan FC microplate. The following formula was used to calculate the relative number of cells attached to the extracellular matrix: average of treated cells OD/average OD control unit. The relative number of cells attached to the extracellular matrix was calculated using the following equation: (mean OD of treated cells/mean OD of control cells) $\times 100 \%(21)$.

\section{Transwell Assay}

A2780 and CP70 cells $\left(2.0 \times 10^{5}\right.$ cells/well in 6-well plates) were added in BD or afatinib or the combination of $\mathrm{BD}$ and afatinib for $48 \mathrm{~h}$. After that, the treated cells were digested, resuspended, and seeded with serum-free media at a density of $1 \times 10^{5} / 100 \mu \mathrm{L}$. Transwell chambers were inserted into a 24well plate and followed with $600 \mu \mathrm{L}$ of medium $10 \%$ FBS added into the lower chamber. The cells were cultivated at $37^{\circ} \mathrm{C}$ for $48 \mathrm{~h}$. Then the fluid and cells in the chamber were thrown away and the edge of chamber was washed by PBS 3 times. The cells were fixed with $4 \%$ paraformaldehyde and then the cells on the chamber membrane were rinsed by pure water. After that, the cells were stained with crystal violet and washed by pure water. The crystals were dissolved by $100 \mu \mathrm{L}$ acetic acid (33\%) and the absorbance were showed at $560 \mathrm{~nm}$ using an automated Thermo Fisher Multiskan FC microplate. The following formula was used to calculate cell migration rate: average of treated cells OD/average OD control unit) $\times 100 \%(21)$.

\section{Statistics}

GraphPad Prism 5 was used for statistical analysis. Results are shown as means \pm SEM and the unpaired student's two-tailed $t$-test was used to determine the statistical significance (ns, not significant; $\left.{ }^{\star} p<0.05 ;{ }^{* \star} p<0.01 ; * \star \star p<0.001\right)$

\section{Results}




\section{Synergistic anticancer effect between BD and afatinib on OC cells}

To verify the relevance between EGFR and prognosis of ovarian cancer, transcriptome data from 1,836 OC tissues were obtained from the TCGA database and analyzed. The results showed that patients expressing higher EGFR showed lower survival rates compared to patients with low EGFR expression (Figure 1A). Therefore, afatinib, a second-generation EGFR inhibitor(25), that binds irreversibly to the EGFR receptor to reduce resistance and recurrence (26),was selected for analysis in this study. First, MTT was performed to evaluate the cytotoxicity of $\mathrm{BD}$ and afatinib against human ovarian cancer cell lines $\mathrm{A} 2780$ and $\mathrm{CP} 70$. The results demonstrated that the $I C_{50}$ values of $\mathrm{BD}$ against $\mathrm{A} 2780$ and $\mathrm{CP} 70$ cells were $0.45 \mu \mathrm{g} / \mathrm{ml}$ and $0.29 \mu \mathrm{g} / \mathrm{ml}$, respectively (Figure 1B). In addition, afatinib was also able to inhibit the cell viability of $A 2780$ and $C P 70$ cells, with $I C_{50}$ values of $3.54 \mu \mathrm{g} / \mathrm{ml}$ and $2.48 \mu \mathrm{g} / \mathrm{ml}$, respectively (Figure 1B). Furthermore, the inhibition of cell growth in the combination group was significantly higher than those in other two single drug groups (Figure 1C and 1D). Finally, the interaction of BD and afatinib was verified by combination index values. Results demonstrated that $B D$ combined with afatinib exhibited a synergistic effect against both OC cell lines A2780 and CP70 (Figure 1E and 1F). Since the combination effect was the strongest in $1 / 4 / C_{50}$ of both $B D$ and afatinib (Figure $1 \mathrm{C}$ and $1 \mathrm{D}$, Supplementary Figure 1 ), this concentration was adopted in the following experiments.

\section{Effects of $\mathrm{BD}$ and afatinb combination treatment on $\mathrm{OC}$ cell proliferation and DNA replication}

To investigate whether the synergistic effects of afatinib and BD extended to inhibit cell proliferation, a colony formation assay and a long-term proliferation assay were performed. The results showed that both the single-drug group and the combined-drug group could inhibit the cell proliferation of OC cell lines A2780 and CP70, while the effect of the combined-drug group is more significant (Figure 1G and $1 \mathrm{H}$ ). Results from the colony formation assay further supported this conclusion that compared to single-drug group, the combination of afatinib and BD resulted in fewer clones of A2780 and CP70 (Figure 1I and 1J). It is of note that this synergistic effects of afatinib and BD failed in MRC5 cells (Figure 1I and $1 \mathrm{~J}$ ). In addition, quantitative analysis of EdU assay indicated that the combination of BD and afatinib significantly inhibited DNA replication in A2780 cells (Figure 2A and 2B). The similar results were also obtained in CP70 cells (Supplementary Figure 2).

\section{Effects of BD and afatinib combination treatment on cell cycle arrest and apoptosis}

To determine whether the growth inhibition of ovarian cancer cells by BD in combination with afatinib is a result of cell cycle arrest, cell cycle distribution was assessed. As expected, when compared to BD and afatinib treated alone, the combination of BD and afatinib significantly blocked A2780 and CP70 cells in the G0/G1 phase (Figure 2C and 2D). To investigate the molecular mechanism of cell cycle arrest by BD and afatinib combination, related cell cycle proteins were detected by western blot analysis. The results suggested that G1 phase protein levels of CDK2 and cyclin D1 were decreased in the combination treatment group, while BD and afatinib treatment alone resulted in no change in amount of CDK2 and 
cyclin D1 in A2780 cells (Figure 2E). Similar results were also observed in CP70 cells (Supplementary Figure 3).

To further investigated the fate of $\mathrm{BD}$ and afatinib combination treated $\mathrm{A} 2780$ and $\mathrm{CP} 70$ cells, we monitored the apoptotic cells after 48 hours of drug treatment. As shown in Figure 3, the amount of BDinduced apoptotic cells increased from $6.3-13.2 \%$ and the amount of afatinib-induced apoptotic cells increased from $6.3-15.8 \%$ in $A 2780$ cells. The amount of apoptotic cells dramatically increased from $6.3-48.9 \%$ in the $B D$ and afatinib combination treatment group (Figure $3 \mathrm{~A}$ and $3 \mathrm{~B}$ ). Similar results were also found in CP70 cells (Supplementary Figure 4A and 4B). This is consistent with the flow cytometry apoptosis results. More cleaved caspase 3 and cleaved poly-ADP ribose polymerase (PARP) were generated with the decreased expression of $\mathrm{Bcl} 2$ in the $\mathrm{BD}$ and afatinib combination treatment groups of A2780 and CP70 cells (Figure 3C and Supplementary Figure 4C). These results suggested that the combination of BD and afatinib could effectively enhance the anticancer activity of BD against $\mathrm{OC}$ cells by promoting cell apoptosis.

\section{Effects of BD and afatinib combination treatment on cell adhesion and migration}

Since cell adhesion plays an important role in OC progression and peritoneal metastases (27). A cell adhesion assay was conducted to test the effects of afatinib and BD combination treatment on the adhesion of $\mathrm{OC}$ cells. The results showed that compared to $\mathrm{BD}$ or afatinib treated cells, cells treated with both $\mathrm{BD}$ and afatinib displayed decreased adhesion to the extracellular matrix (Figure 4A and 4B). It is widely known that cell adhesion is closely related to cell migration and invasion. In this context, decreased cell adhesion might reduce cell migration. A transwell assay was performed to better determine the abilities of cell migration. These results indicated that BD and afatinib combination treated cells displayed a weakened ability to traverse a membrane from the serum-free to serum side $(10 \% \mathrm{FBS})$ compared to untreated cells, or those that were treated with only one drug (Figure 4C and 4D).

\section{Effects of BD and afatinb combination treatment on EGFR signaling, DNA damage and DNA damage repair}

To further explored the underlying mechanism of the combination treatment of BD and afatinib against $\mathrm{OC}$ and the synergistic interaction between $\mathrm{BD}$ and afatinib, we first evaluated the EGFR signaling pathway in ovarian cancer cells A2780 and CP70 after treatment with BD and afatinib either alone or in combination. As shown in Figure $5 \mathrm{~A}$ and $5 \mathrm{~B}$, treatment with afatinib and/or $\mathrm{BD}$ alone resulted in a decreased level of $p$-EGFR and p-AKT; however, the total protein content of EGFR and AKT remained unchanged in both A2780 and CP70 cell lines at 48 hours. As expected, the inhibition effect of p-EGFR caused by $B D$ was more weaken than afatinib (Figure $5 A$ and $5 B$ ). Surprisingly, the combined treatment with both $B D$ and afatinib resulted in further inhibition of $p-A K T$ (Figure $5 A$ and $5 B$ ).

Considering the positive correlation among $\mathrm{p}-\mathrm{AKT}$ and DNA damage, comet assays were performed to investigate the DNA damage in cells treated with $\mathrm{BD}$ or afatinib alone, and in $\mathrm{BD}$ and afatinib combination treated cells. The results showed that the DNA damage was the most obvious in the 
combined treatment group, with the DNA fragments that leave the genome forming a "tail" (Figure 5C). Quantitative analysis revealed that combined treatment triggered more DNA damage than BD or afatinib treatment alone (Figure 5D). Immunofluorescence assays using 53BP1 as a DNA double-strand break marker (28) were performed to verify this result. The results found that 53BP1 foci per cell accumulated significantly in the combination treatment group as compared to the single drug treatment in both A2780 and CP70 cells (Figure 6A-6D). These results suggest that there might be some DNA damage repair problems in both $\mathrm{BD}$ and afatinib treated cells. Consistent with this, the results from western blot analysis showed that in the combination group, $\mathrm{Y}-\mathrm{H} 2 \mathrm{AX}$ was significantly increased, while the proteins related to DNA repair, such as RPA, Rad51, and Ku70, were decreased significantly (Figure 6E and 6F). Together, all results demonstrated that BD combined with afatinib blocked EGFR signaling, DNA damage, and DNA damage repair in $\mathrm{OC}$ cells.

\section{Discussion}

Previous studies have shown that the expression of EGFR had a positive correlation with OC and that its inhibitors could enhance the anticancer activity of chemotherapy drugs in the setting of some cancers (29). However, whether a combination of afatinib, an EGFR inhibitor, and BD, a traditional Chinese medicine antitumor drug, would achieve success in $\mathrm{OC}$ is not yet known. In this study, we first evaluated the anticancer activity of the combination of $\mathrm{BD}$ and afatinib combination in $\mathrm{OC}$. Our results demonstrated that compared to treatment with $\mathrm{BD}$ or afatinib alone, the combination treatment possessed a stronger ability to influence cell proliferation and migration inhibition, which led to more cell apoptosis. Furthermore, we revealed that this stronger, anticancer effects of the combination treatment is the consequence of the dual blocking of the EGFR and DNA damage repair signaling pathway.

Although EGFR inhibitors have been widely used in the clinical treatment of EGFR-mutated cancers, they application was limited due to the drug resistance (30). Since EGFR inhibitors have the anticancer activity and enhancing effects of other chemotherapy drugs, this combination treatment strategy is another important development to determine the full effects of an EGFR inhibitor; however, EGFR mutations in the setting of $\mathrm{OC}$ are rare (31). The combination effect on $\mathrm{OC}$ along with the underlying mechanism is an important question to solve. We found that BD has anti-proliferation and anti-migration effects on ovarian cancer cell lines A2780 and CP70. When combined with afatinib, the effect of anti-migration and anti-cloning is more significant (Figures 1 and 4). This suggests that combination treatment may result in a simultaneous blockade of multiple survival and migration pathways, including EGFR signaling. Consistently, our results indicated that in addition to blocking the EGFR signaling pathway, BD combined with afatinib triggered intense DNA damage and provoked stronger DNA damage but suppressed the DNA damage repair signaling. Both strategies lead to catastrophic DNA damage that causes cell death (32).

DNA-PKcs is phosphorylated at Thr2609 to respond to DNA damage caused by anti-cancer drugs, which is a significant step for the ability of DNA repair (33). To repair damaged DNA, DNA-PKcs recruits other proteins, like Ku70 (34). Some studies suggested that EGFR binds to DNA-PKcs and induces its phosphorylation (34). We found that the combination of BD and afatinib can truly inhibit Ku70 and EGFR 
expression (Figures 5A, 5B and 6E, 6F). So, it is reasonable to assume that BD combined with afatinib may block DNA damage repair signaling by EGFR-mediated Ku70 expression.

In summary, our study not only suggests a possible role of BD in anti-ovarian cancer, but also shows that combination with afatinib significantly inhibits tumor growth and migration. This combination may provide benefits in the treatment of OC. Further research in vivo is also warranted to fully elucidate the value of $\mathrm{BD}$ combined with afatinib as a treatment option for $\mathrm{OC}$.

\section{Abbreviations}

Ovarian cancer, OC; epidermal growth factor receptor, EGFR; Bruceine D, BD; 3-(4, 5-dimethylthiadiazole-2yl)-2, 5-diphenyltetrazolium bromide, MTT; combination index, Cl; Immunofluorescence assays, IF

\section{Declarations}

\section{Acknowledgements}

The present study was funded by National Science Foundation of China (No. 81803781), Natural Science Foundation of Zhejiang Province(No. LQ21H160044), We thank LetPub (www.letpub.com) for its linguistic assistance during the preparation of this manuscript.

\section{Author Contributions}

Feng Lin, Ju-fan Zhu and Luo Wang performed experiments and wrote the manuscript. Yuan-jun Yang and Ru-ru Zheng analyzed the data. Xu Zhang and Yan Hu designed the research and revised the manuscript.

\section{Data AvailabilityStatement}

All data in this study are available if requested.

\section{Supplementary Information}

The Supplementary Material for this article can be found online.

\section{Statements and Declarations}

The authors have no conflicts of interest to declare.

\section{References}

1. Merlo S, Besic N, Drmota E, Kovacevic N. Preoperative serum CA-125 level as a predictor for the extent of cytoreduction in patients with advanced stage epithelial ovarian cancer. Radiol Oncol. 2021;55(3):341-6. 
2. Lin N, Lin JZ, Tanaka Y, et al. Identification and validation of a five-IncRNA signature for predicting survival with targeted drug candidates in ovarian cancer. Bioengineered. 2021;12(1):3263-74.

3. Lheureux S, Gourley C, Vergote I, Oza AM. Epithelial ovarian cancer. Lancet. 2019;393(10177):124053.

4. Agarwal R, Kaye SB. Ovarian cancer: strategies for overcoming resistance to chemotherapy. Nat Rev Cancer. 2003;3(7):502-16.

5. Meyers N, Gerard C, Lemaigre FP, Jacquemin P. Differential impact of the ERBB receptors EGFR and ERBB2 on the initiation of precursor lesions of pancreatic ductal adenocarcinoma. Sci Rep. 2020;10(1):5241.

6. Areeb Z, Stuart SF, West AJ, et al. Reduced EGFR and increased miR-221 is associated with increased resistance to temozolomide and radiotherapy in glioblastoma. Sci Rep. 2020;10(1):17768.

7. Roskoski R, Jr. Small molecule inhibitors targeting the EGFR/ErbB family of protein-tyrosine kinases in human cancers. Pharmacol Res. 2019;139:395-411.

8. Lin CC, Huang YK, Cho CF, et al. Targeting positive feedback between BASP1 and EGFR as a therapeutic strategy for lung cancer progression. Theranostics. 2020;10(24):10925-39.

9. Lafky JM, Wilken JA, Baron AT, Maihle NJ. Clinical implications of the ErbB/epidermal growth factor (EGF) receptor family and its ligands in ovarian cancer. Biochim Biophys Acta. 2008;1785(2):232-65.

10. Tuefferd M, Couturier J, Penault-Llorca F, et al. HER2 status in ovarian carcinomas: a multicenter GINECO study of 320 patients. PLoS One. 2007;2(11):e1138.

11. Brown BP, Zhang YK, Westover D, et al. On-target Resistance to the Mutant-Selective EGFR Inhibitor Osimertinib Can Develop in an Allele-Specific Manner Dependent on the Original EGFR-Activating Mutation. Clin Cancer Res. 2019;25(11):3341-51.

12. Modjtahedi H, Cho BC, Michel MC, Solca F. A comprehensive review of the preclinical efficacy profile of the ErbB family blocker afatinib in cancer. Naunyn Schmiedebergs Arch Pharmacol. 2014;387(6):505-21.

13. Chavda VP, Ertas YN, Walhekar V, et al. Advanced Computational Methodologies Used in the Discovery of New Natural Anticancer Compounds. Front Pharmacol. 2021;12:702611.

14. Yang Y, Kong F, Ding Q, et al. Bruceine D elevates Nrf2 activation to restrain Parkinson's disease in mice through suppressing oxidative stress and inflammatory response. Biochem Biophys Res Commun. 2020;526(4):1013-20.

15. Li L, Dong Z, Shi P, et al. Bruceine D inhibits Cell Proliferation Through Downregulating LINC01667/MicroRNA-138-5p/Cyclin E1 Axis in Gastric Cancer. Front Pharmacol. 2020;11:584960.

16. Bruceine $D$ induces apoptosis in human chronic myeloid leukemia $\mathrm{K} 562$ cells via mitochondrial pathwayCheng Z, Yuan X, Qu Y, et al. Bruceine D inhibits hepatocellular carcinoma growth by targeting beta-catenin/jagged1 pathways. Cancer Lett. 2017;403:195-205.

17. Zhang JY, Lin MT, Tung HY, et al. Bruceine D induces apoptosis in human chronic myeloid leukemia K562 cells via mitochondrial pathway. Am J Cancer Res. 2016;6(4):819-26. 
18. Lau ST, Lin ZX, Liao Y, et al. Bruceine D induces apoptosis in pancreatic adenocarcinoma cell line PANC-1 through the activation of p38-mitogen activated protein kinase. Cancer Lett. 2009;281(1):4252.

19. Lau ST, Lin ZX, Leung PS. Role of reactive oxygen species in brucein D-mediated p38-mitogenactivated protein kinase and nuclear factor-kappaB signalling pathways in human pancreatic adenocarcinoma cells. Br J Cancer. 2010;102(3):583-93.

20. Cheng Z, Yuan X, Qu Y, et al. Bruceine D inhibits hepatocellular carcinoma growth by targeting betacatenin/jagged1 pathways. Cancer Lett. 2017;403:195-205.

21. Chen X, Wang G, Mohammed Alsayed AM, et al. Synthesis and biological evaluation of novel Nsubstituted benzamides as anti-migration agents for treatment of osteosarcoma. Eur $\mathrm{J}$ Med Chem. 2021;214:113203.

22. Yang Z, Pan Q, Zhang D, et al. Silibinin restores the sensitivity of cisplatin and taxol in A2780resistant cell and reduces drug-induced hepatotoxicity. Cancer Manag Res. 2019;11:7111-22.

23. Chen J, Jin X, Mei Y, et al. The different biological effects of TMPyP4 and cisplatin in the inflammatory microenvironment of osteosarcoma are attributed to G-quadruplex. Cell Prolif. 2021;54(9):e13101.

24. Chen J, Jin X, Shen Z, et al. H2O2 enhances the anticancer activity of TMPyP4 by ROS-mediated mitochondrial dysfunction and DNA damage. Med Oncol. 2021;38(6):59.

25. Lu S, Shih JY, Jang TW, et al. Afatinib as First-Line Treatment in Asian Patients with EGFR MutationPositive NSCLC: A Narrative Review of Real-World Evidence. Adv Ther. 2021;38(5):2038-53.

26. Niederst MJ, Sequist LV, Poirier JT, et al. RB loss in resistant EGFR mutant lung adenocarcinomas that transform to small-cell lung cancer. Nat Commun. 2015;6:6377.

27. El-Mais N, Fakhoury I, Abdellatef S, et al. Human recombinant arginase I [HuArgl (Co)-PEG5000]induced arginine depletion inhibits ovarian cancer cell adhesion and migration through autophagymediated inhibition of RhoA. J Ovarian Res. 2021;14(1):13.

28. Shanbhag NM, Evans MD, Mao W, et al. Early neuronal accumulation of DNA double strand breaks in Alzheimer's disease. Acta Neuropathol Commun. 2019;7(1):77.

29. Hassan W, Chitcholtan K, Sykes P, Garrill A. Ascitic fluid from advanced ovarian cancer patients compromises the activity of receptor tyrosine kinase inhibitors in $3 \mathrm{D}$ cell clusters of ovarian cancer cells. Cancer Lett. 2018;420:168-81.

30. Okura N, Nishioka N, Yamada T, et al. ONO-7475, a Novel AXL Inhibitor, Suppresses the Adaptive Resistance to Initial EGFR-TKI Treatment in EGFR-Mutated Non-Small Cell Lung Cancer. Clin Cancer Res. 2020;26(9):2244-56.

31. Murphy M, Stordal B. Erlotinib or gefitinib for the treatment of relapsed platinum pretreated non-small cell lung cancer and ovarian cancer: a systematic review. Drug Resist Updat. 2011;14(3):177-90.

32. Gee ME, Faraahi Z, McCormick A, Edmondson RJ. DNA damage repair in ovarian cancer: unlocking the heterogeneity. J Ovarian Res. 2018;11(1):50. 
33. Zhang S, Matsunaga S, Lin YF, et al. Spontaneous tumor development in bone marrow-rescued DNA$\mathrm{PKcs}(3 \mathrm{~A} / 3 \mathrm{~A})$ mice due to dysfunction of telomere leading strand deprotection. Oncogene. 2016;35(30):3909-18.

34. Zhou Z, Lu H, Zhu S, et al. Activation of EGFR-DNA-PKcs pathway by IGFBP2 protects esophageal adenocarcinoma cells from acidic bile salts-induced DNA damage. J Exp Clin Cancer Res. 2019;38(1):13.

\section{Figures}


A

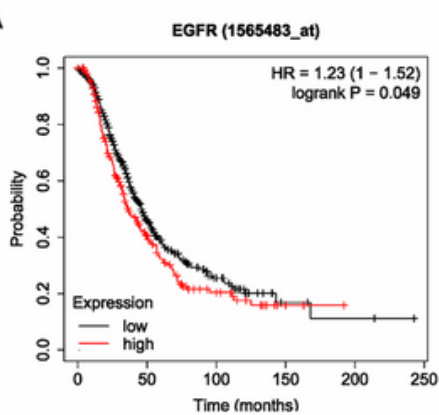

C

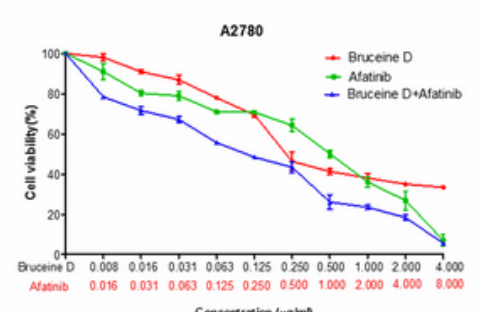

Concertraxion (uggmm)

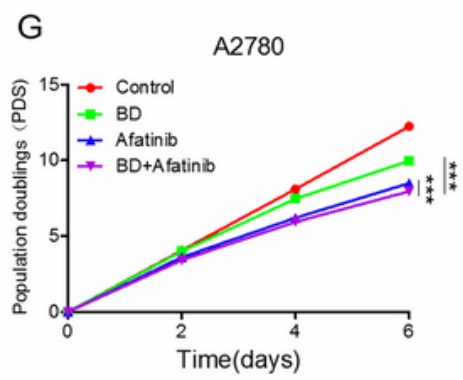

I

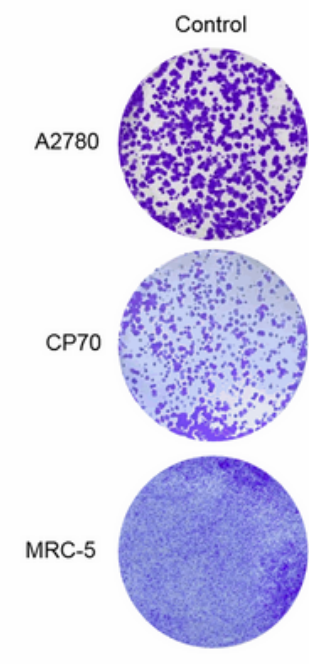

B

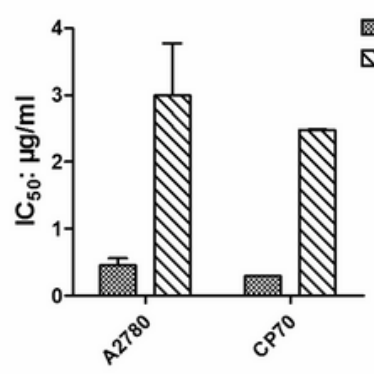

D

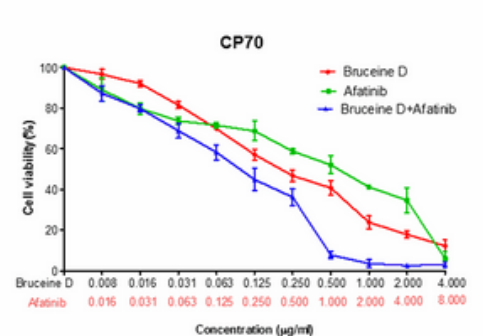

$\mathrm{H}$

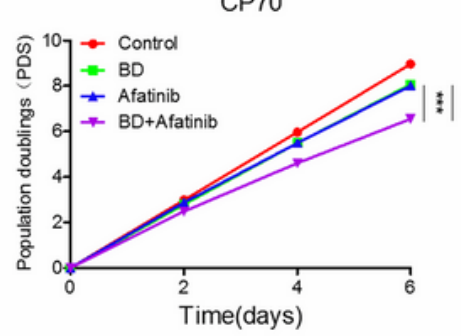

$\mathrm{J}$
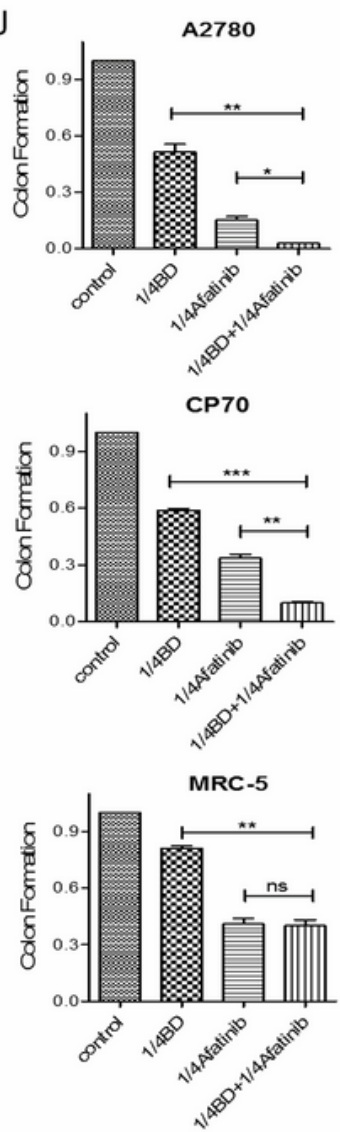

\section{Figure 1}

The synergistic anticancer effects of BD and afatinib on ovarian cancer.A,Kaplane-Meier analysis was performed and found a negative correlation between EGFR expression and overall survival of ovarian cancer patients. Data were obtained from TCGA.B, along with the IC50 values of ovarian cancer A2780 and CP70 cells. $C$ and D, The A2780 and CP70 cells were treated with BD, afatinib, or BD combined with afatinib at the indicated concentration for 48 hours. Then, the cell viability was detected with the use of 
MTT assay.E and F,Combination index $(\mathrm{Cl})$ values of the combination treatment were calculated using Calcusyn Software.G and H, Proliferation curves of A2780 and CP70 cells in the presence of BD $(0.113$ $\mu \mathrm{g} / \mathrm{ml})$, afatinib $(0.885 \mu \mathrm{g} / \mathrm{ml})$, or the combination of $B D(0.113 \mu \mathrm{g} / \mathrm{ml})$ and afatinib $(0.885 \mu \mathrm{g} / \mathrm{ml})$ for 48 hours. I, Clone formation assay of A2780, CP70 and MRC-5 cells with BD $(0.113 \mu \mathrm{g} / \mathrm{ml})$, afatinib $(0.885$ $\mu \mathrm{g} / \mathrm{ml})$, or the combination of BD $(0.113 \mu \mathrm{g} / \mathrm{ml})$ and afatinib $(0.885 \mu \mathrm{g} / \mathrm{ml})$ for 48 hours.J, Quantification of I. Statistical significance was analyzed using unpaired student's two-tailed t-tests (ns, not significant, $\left.{ }^{*} \mathrm{p}<0.05,{ }^{* *} \mathrm{p}<0.01,{ }^{* *} \mathrm{p}<0.001\right)$.

A

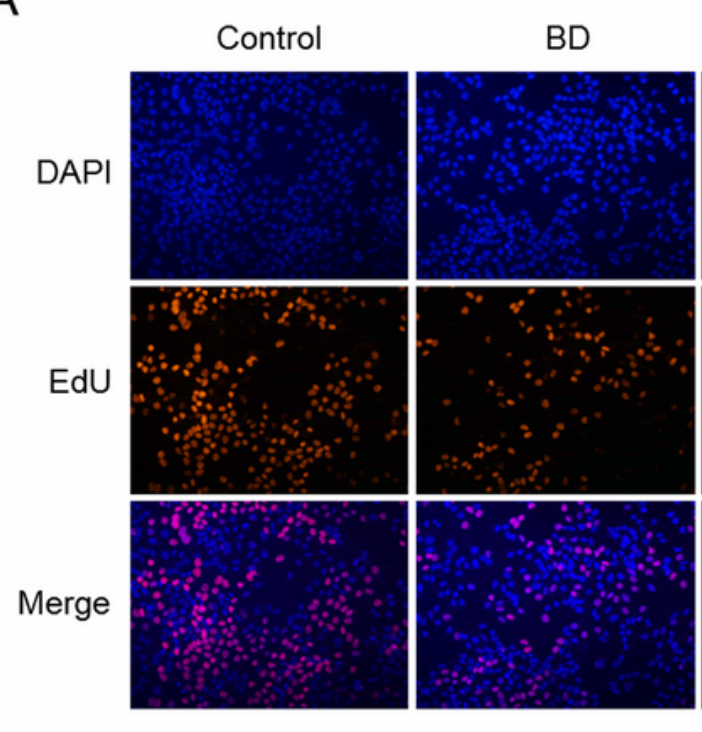

Afatinib

$B D+$ Afatinib
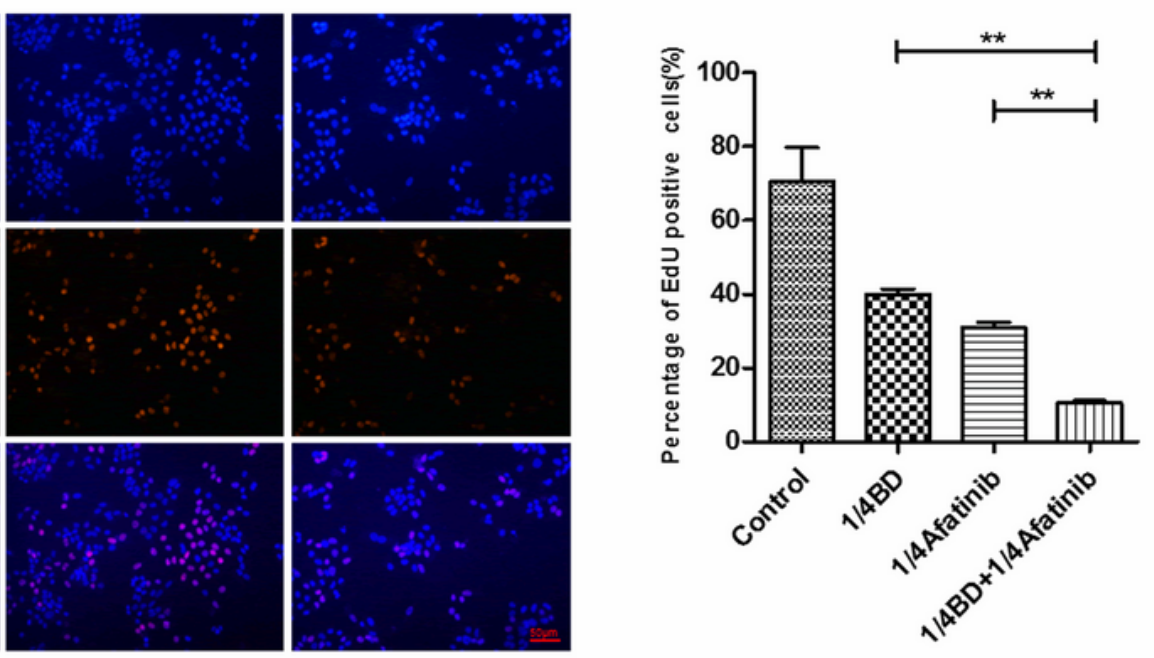

C
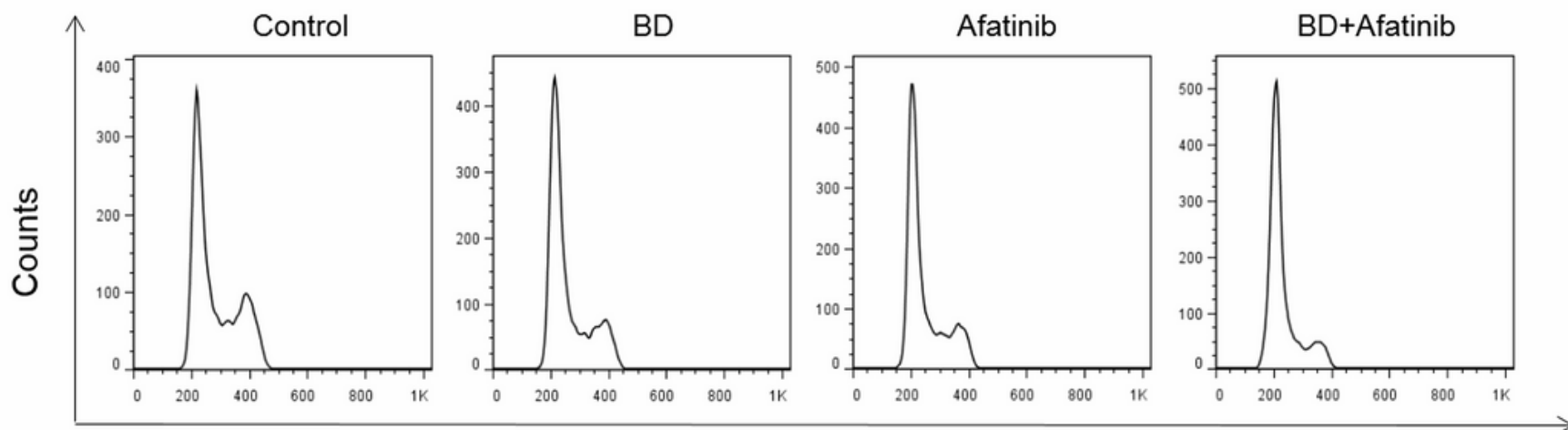

PI staining intensity

D

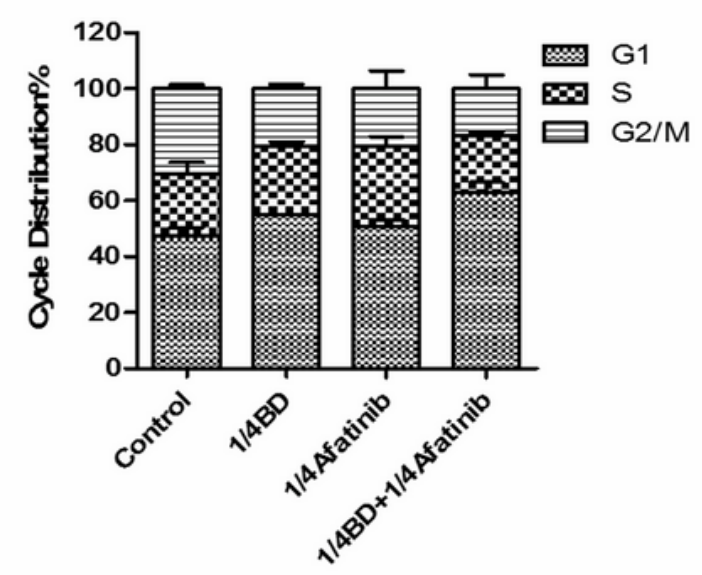

E

\begin{tabular}{|c|c|c|c|c|}
\hline $\mathrm{BD}(\mu \mathrm{g} / \mathrm{ml})$ & 0 & 0.113 & 0 & 0.113 \\
\hline Afatinib $(\mu \mathrm{g} / \mathrm{ml}$ & ) 0 & 0 & 0.885 & 0.885 \\
\hline Cyclin D1 & 0 & $=$ & 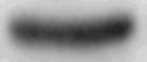 & 0 \\
\hline CDK2 & & & 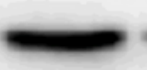 & 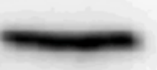 \\
\hline GAPDH & & & & \\
\hline
\end{tabular}


Figure 2

The combination of BD and afatinib slowed down DNA repair rate and induced cell cycle G0/G1 arrest.

A,EdU staining for cell proliferation and evaluation of A2780 cells. B, Quantification of A. C, FACS analysis of the cell cycle of $A 2780$ cells in the presence of $B D(0.113 \mu \mathrm{g} / \mathrm{ml})$, afatinib $(0.885 \mu \mathrm{g} / \mathrm{ml})$, or the combination of BD $(0.113 \mu \mathrm{g} / \mathrm{ml})$ and afatinib $(0.885 \mu \mathrm{g} / \mathrm{ml})$ for 48 hours. D, Quantification of C. E, Western blot analysis of cyclin D1 and CDK2 of A2780 cells in the presence of BD $(0.113 \mu \mathrm{g} / \mathrm{ml})$, afatinib $(0.885 \mu \mathrm{g} / \mathrm{ml})$, or the combination of $B D(0.113 \mu \mathrm{g} / \mathrm{ml})$ and afatinib $(0.885 \mu \mathrm{g} / \mathrm{ml})$ for 48 hours. GAPDH was used as a loading control. Statistical significance was analysed using unpaired student's two-tailed t-tests (ns, not significant, $\left.{ }^{*} \mathrm{p}<0.05,{ }^{* \star} \mathrm{p}<0.01,{ }^{* * *} \mathrm{p}<0.001\right)$.

A
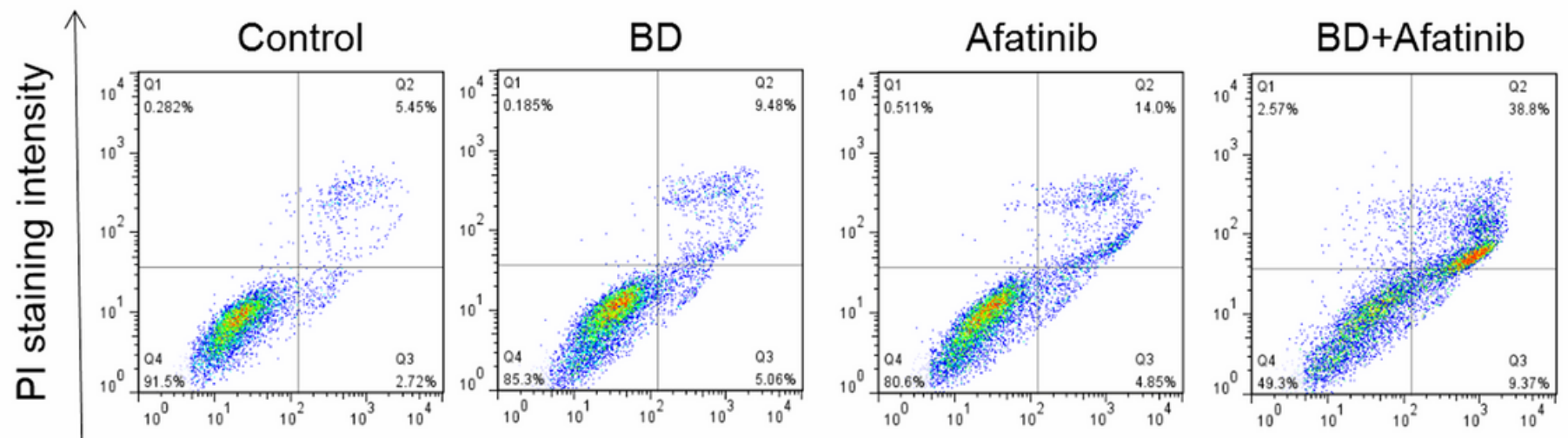

Annexin $\mathrm{V}$ staining intensity

B

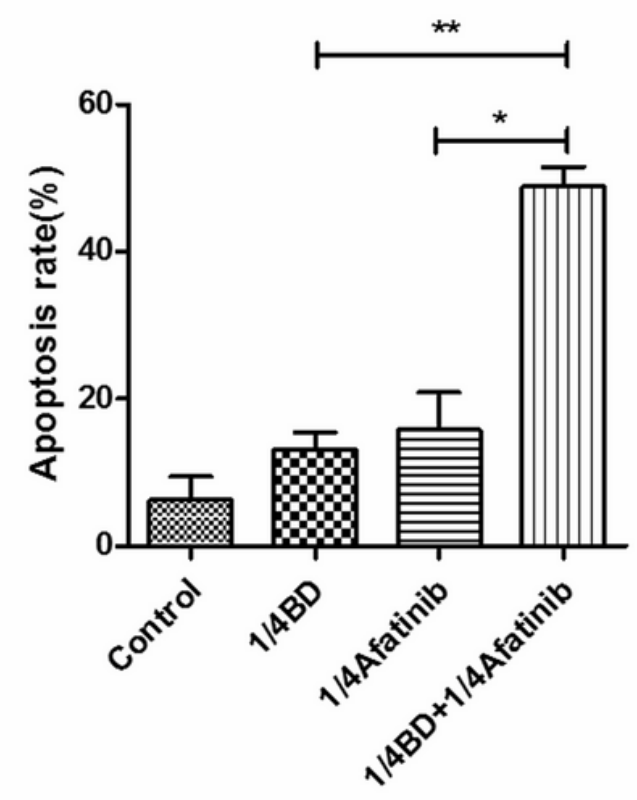

C

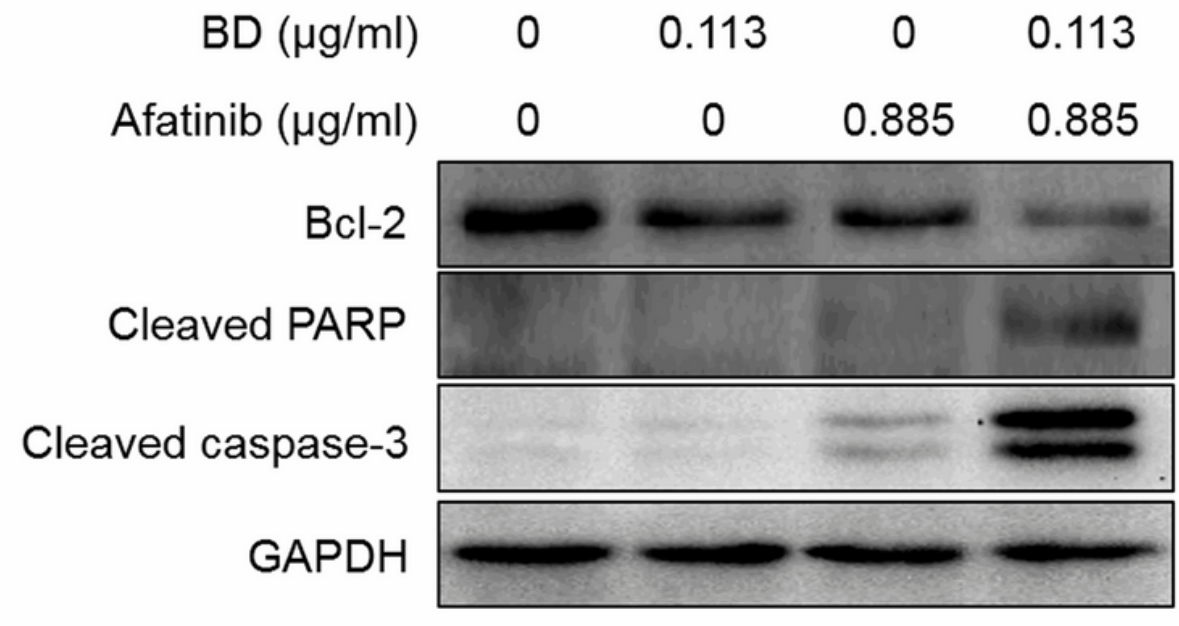

Figure 3 
The combination of BD and afatinib induced apoptosis of A2780 cells.A, A2780 cells were treated with $\mathrm{BD}(0.113 \mu \mathrm{g} / \mathrm{ml})$, afatinib $(0.885 \mu \mathrm{g} / \mathrm{ml})$, or the combination of BD $(0.113 \mu \mathrm{g} / \mathrm{ml})$ and afatinib $(0.885$ $\mu \mathrm{g} / \mathrm{ml}$ ) for 48 hours. Apoptotic cells were assayed by Annexin V/PI staining and FACS analysis. B, Quantification of A. C, Western blot analysis of Bcl-2, cleaved PARP, and cleaved caspase-3 of A2780 cells in the presence of $B D(0.113 \mu \mathrm{g} / \mathrm{ml})$, afatinib $(0.885 \mu \mathrm{g} / \mathrm{ml})$, or the combination of $B D(0.113 \mu \mathrm{g} / \mathrm{ml})$ and afatinib $(0.885 \mu \mathrm{g} / \mathrm{ml})$ for 48 hours. GAPDH was used as a loading control. Statistical significance was analysed using unpaired student's two-tailed t-tests (ns, not significant, ${ }^{*} p<0.05,{ }^{* *} p<0.01,{ }^{* \star *} p<0.001$ ).

A

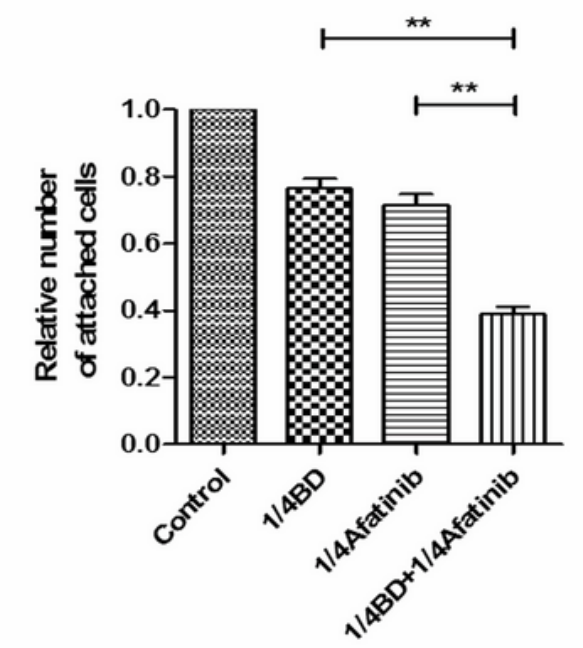

$\mathrm{B}$

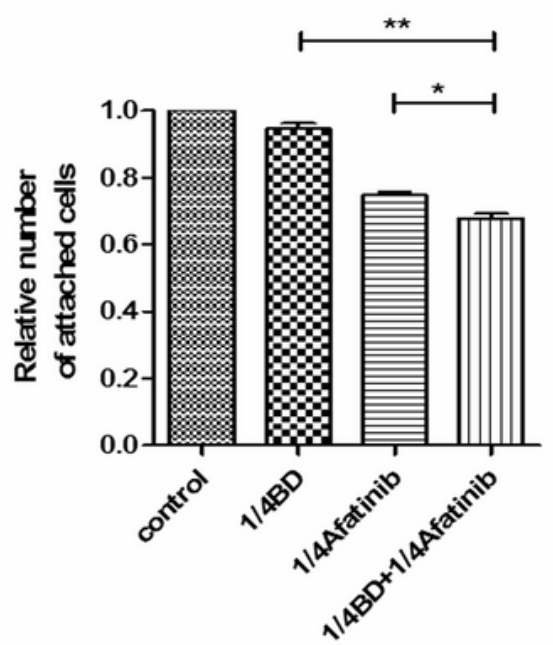

C

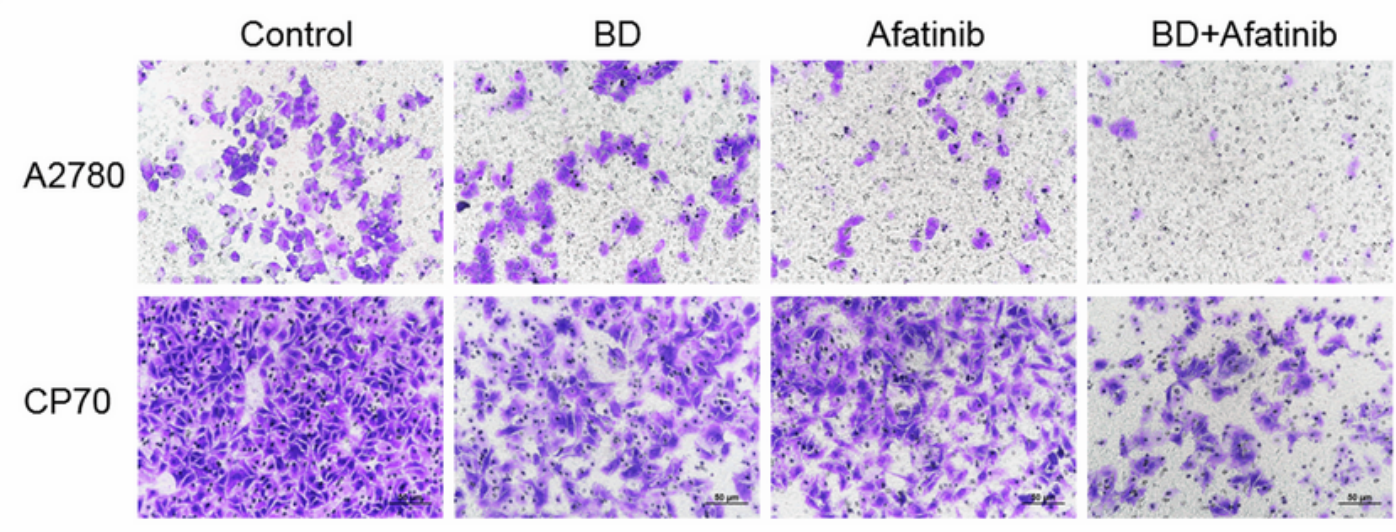

D

A2780

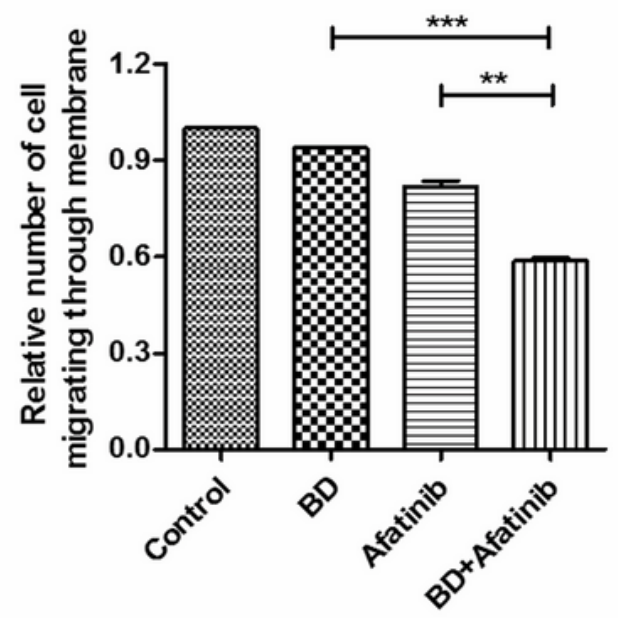

CP70

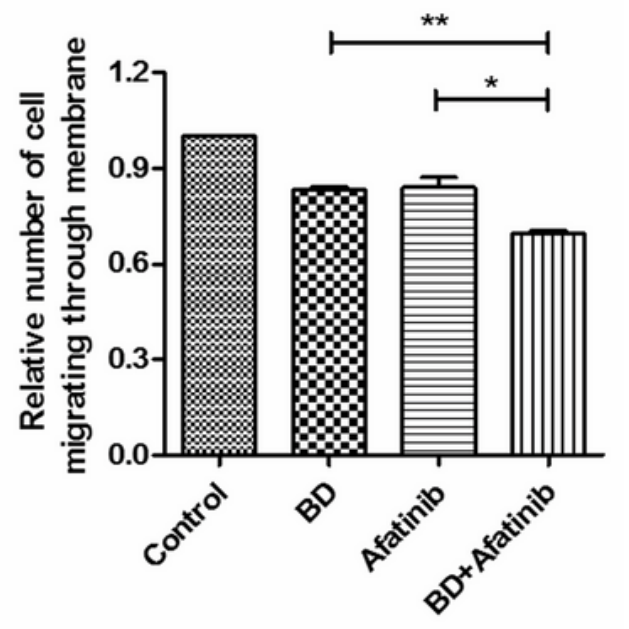




\section{Figure 4}

The combination of BD and afatinib inhibited adhesion and migration of $A 2780$ and $C P 70$ cells. $A$ and $B$, $A 2780$ and CP70 cells were treated with $B D(0.113 \mu \mathrm{g} / \mathrm{ml})$, afatinib $(0.885 \mu \mathrm{g} / \mathrm{ml})$, or the combination of $\mathrm{BD}(0.113 \mu \mathrm{g} / \mathrm{ml})$ and afatinib $(0.885 \mu \mathrm{g} / \mathrm{ml})$ for 48 hours, which decreased cell adhesion to extracellular matrix in cell adhesion assay. C, A2780 and CP70 cells were treated with $B D(0.113 \mu \mathrm{g} / \mathrm{ml})$, afatinib $(0.885$ $\mu \mathrm{g} / \mathrm{ml})$, or the combination of $\mathrm{BD}(0.113 \mu \mathrm{g} / \mathrm{ml})$ and afatinib $(0.885 \mu \mathrm{g} / \mathrm{ml})$ for 48 hours. This inhibited cell migration and invasion in the transwell assay. D, Quantification of $C$ was assessed. Statistical significance was analysed using unpaired student's two-tailed t-tests (ns, not significant, ${ }^{*} p<0.05$, $\left.{ }^{* \star} p<0.01,{ }^{* \star *} p<0.001\right)$. 
B

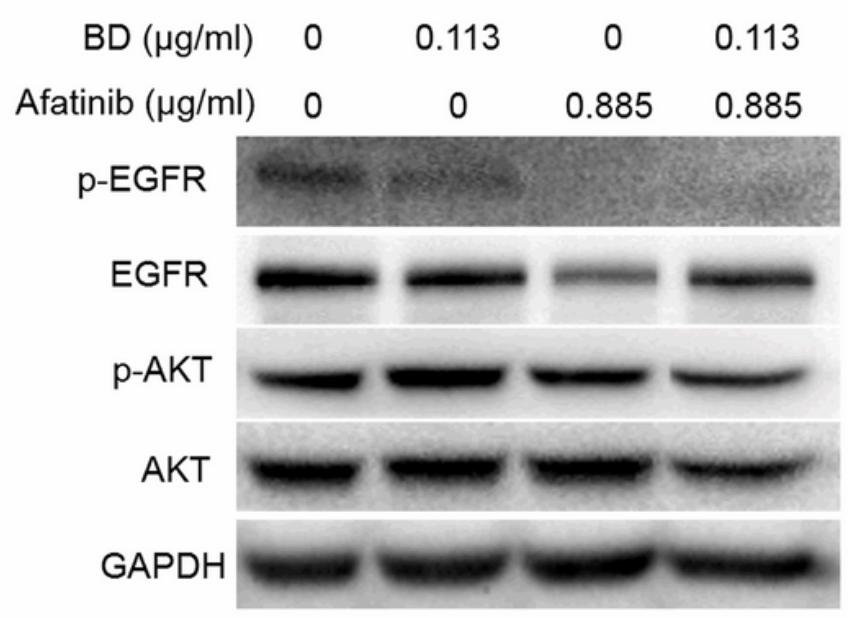

A2780

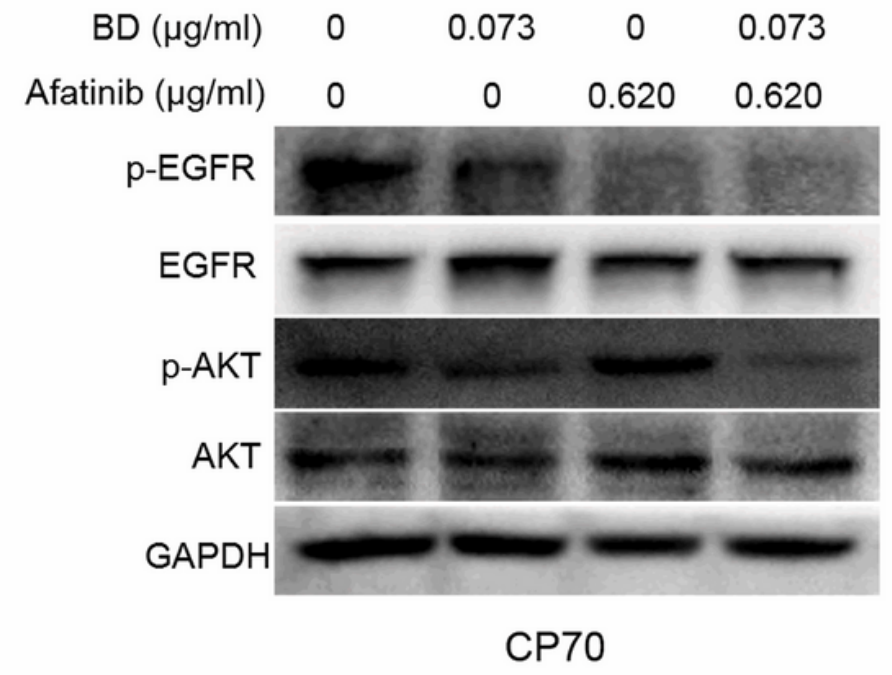

C

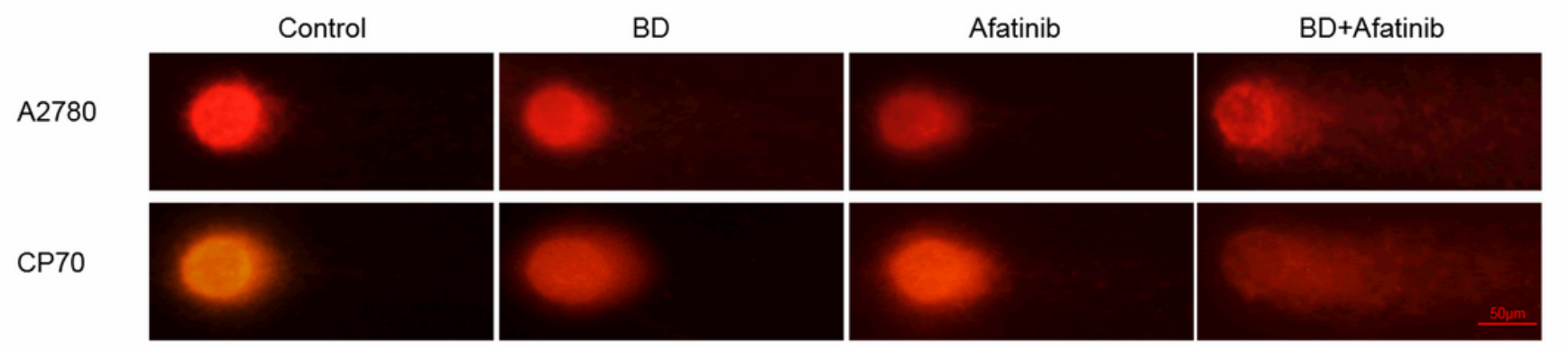

D
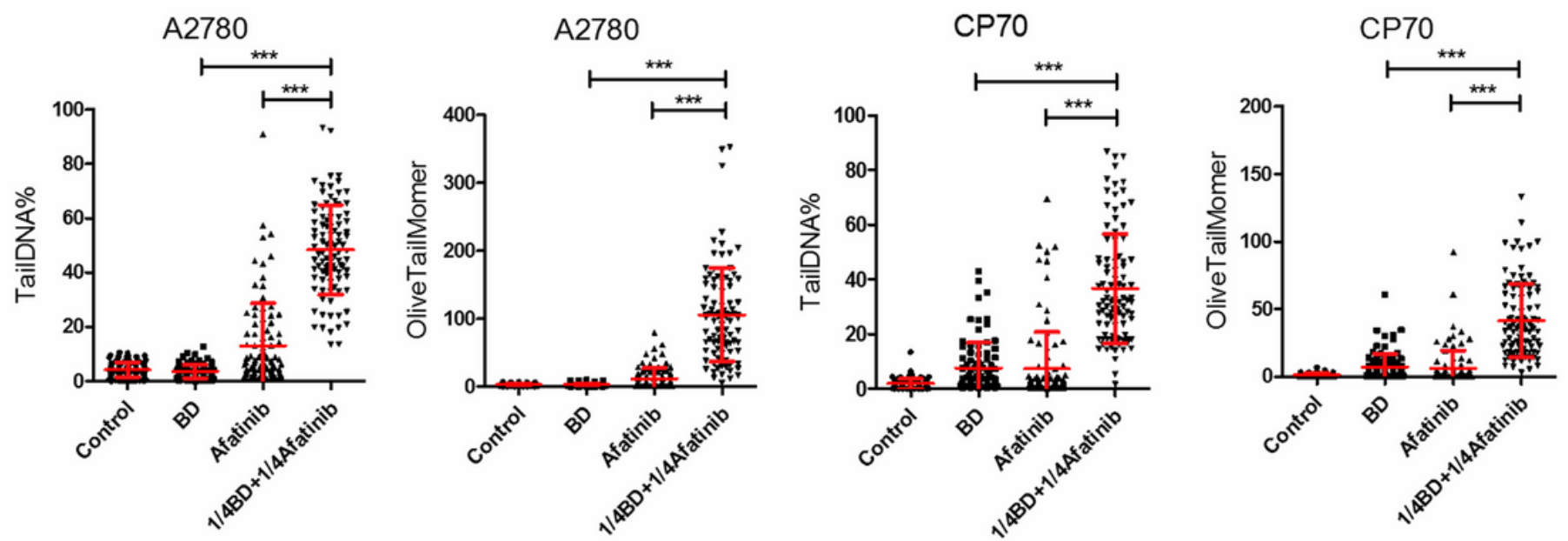

\section{Figure 5}

The combination of BD and afatinib blocks the EGFR pathway and triggers DNA damage of A2780 and CP70 cells.A andB, Western blot analysis of EGFR, p-EGFR, AKT, and p-AKTof A2780 and CP70 cells was performed in the presence of $B D(0.113 \mu \mathrm{g} / \mathrm{ml})$, afatinib $(0.885 \mu \mathrm{g} / \mathrm{ml})$, or the combination of BD $(0.113$ $\mu \mathrm{g} / \mathrm{ml})$ and afatinib $(0.885 \mu \mathrm{g} / \mathrm{ml})$ for 48 hours. GAPDH was used as loading control. C, Comet assay in alkaline conditions was used to detect the DNA damage of A2780 and CP70 cells treated with BD (0.113 $\mu \mathrm{g} / \mathrm{ml})$, afatinib $(0.885 \mu \mathrm{g} / \mathrm{ml})$, or the combination of BD $(0.113 \mu \mathrm{g} / \mathrm{ml})$ and afatinib $(0.885 \mu \mathrm{g} / \mathrm{ml})$ for 48 
hours. D, Then, quantification of tail DNA (\%) and olive tail moment under alkaline conditions of A2780 and CP70 cells was assessed. Statistical significance was analysed using unpaired student's two-tailed ttests (ns, not significant, ${ }^{*} p<0.05,{ }^{*} p<0.01,{ }^{* * *} p<0.001$ ).

A

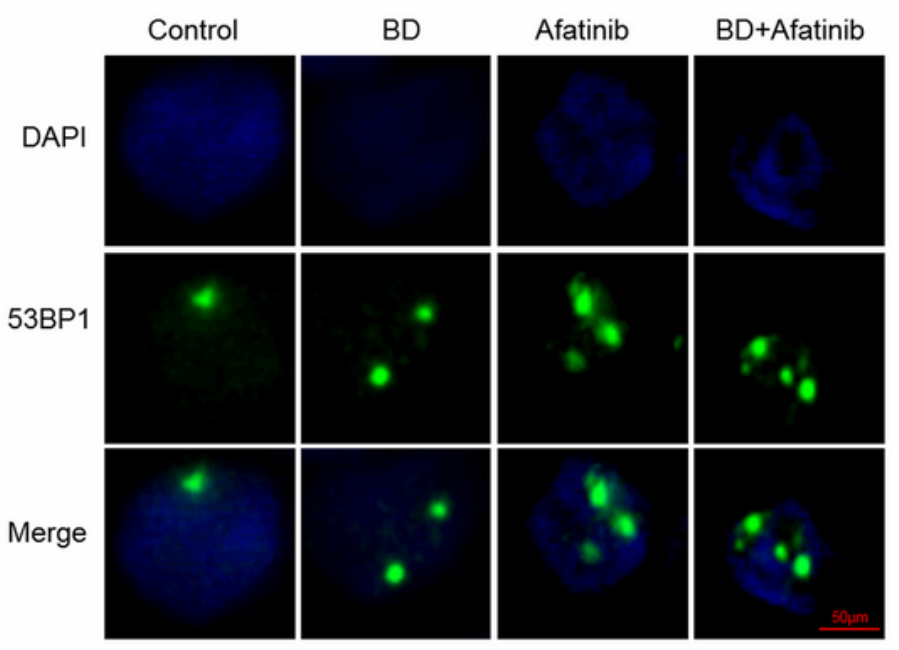

B

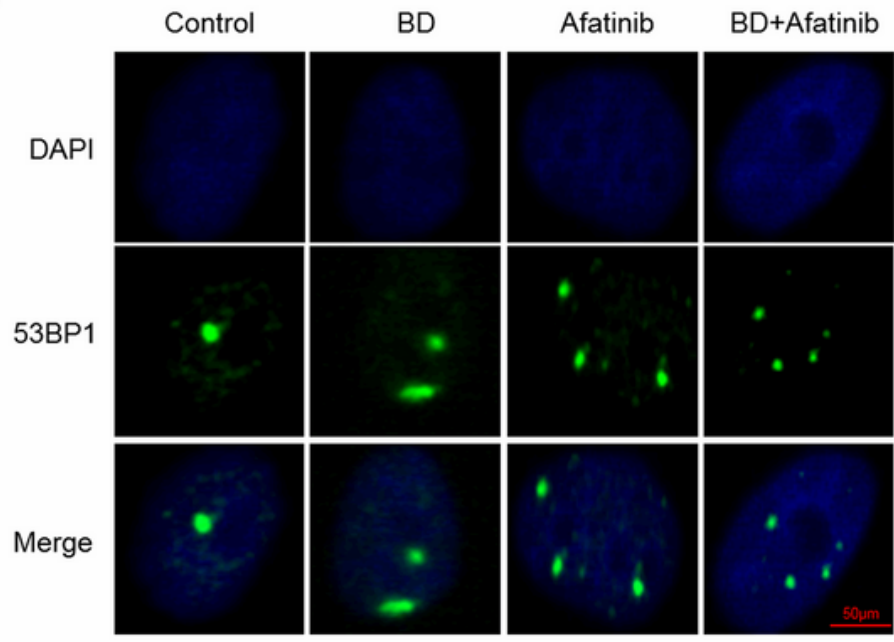

$E$

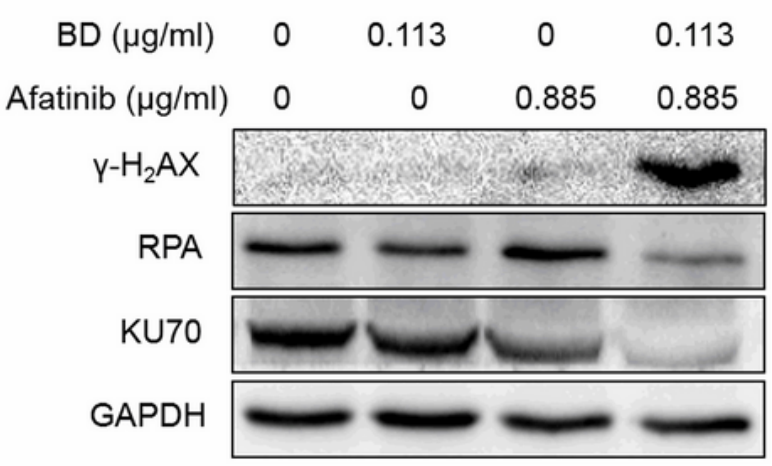

A2780
C

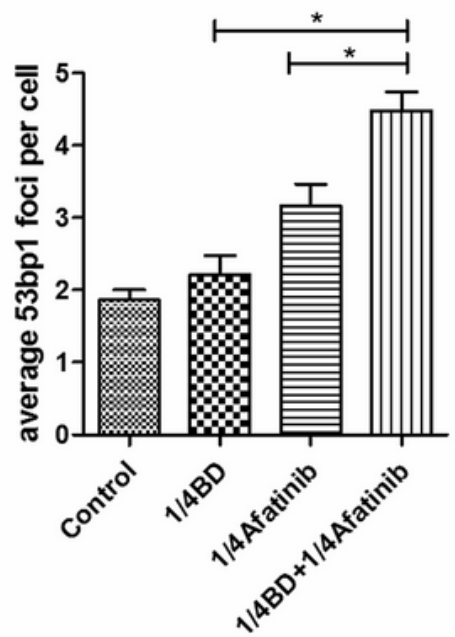

D

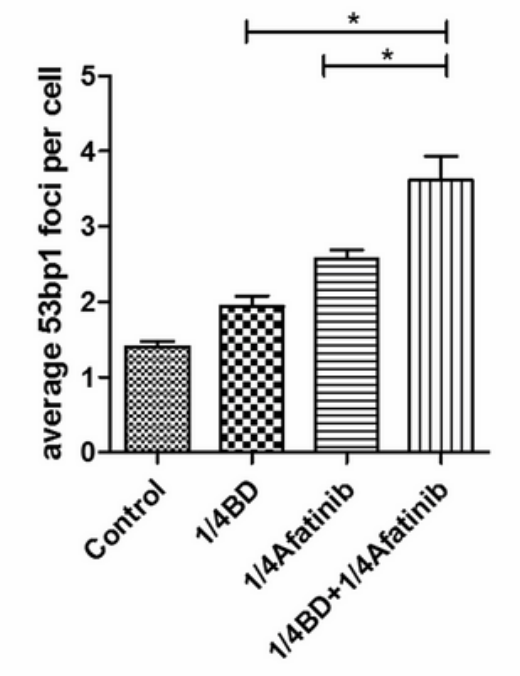

$\mathrm{F}$

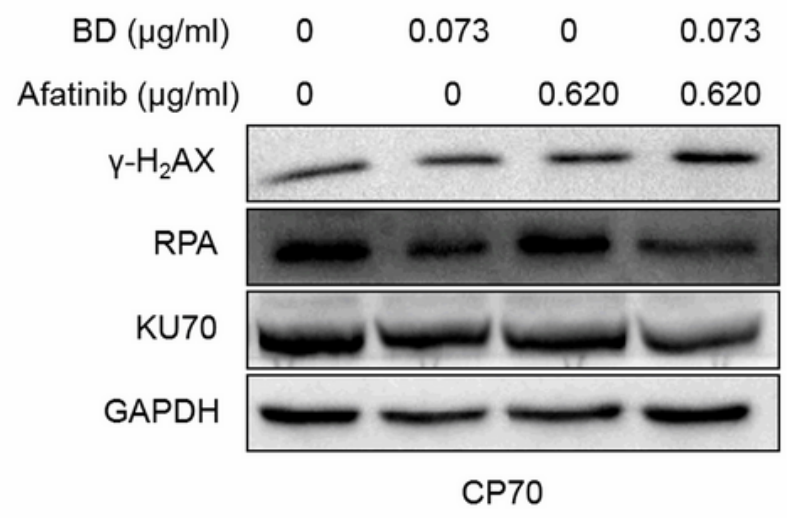

Figure 6

The combination of $\mathrm{BD}$ and afatinib provoked a strong DNA damage response.A and $\mathrm{B}$, Immunofluorescence (IF) assay with 53BP1 antibody was used to detect the 53BP1 foci in drug treated or 
untreated A2780 and CP70 cells. A2780 and CP70 cells were treated with BD $(0.113 \mu \mathrm{g} / \mathrm{ml})$, afatinib $(0.885 \mu \mathrm{g} / \mathrm{ml})$, or the combination of $B D(0.113 \mu \mathrm{g} / \mathrm{ml})$ and afatinib $(0.885 \mu \mathrm{g} / \mathrm{ml})$ for 48 hours. DAPI and 53BP1 were used as the nucleus dye (blue) and DNA damage marker (green), respectively. C and D, Then, quantification of the numbers of 53BP1 foci of A2780 and CP70 cells was assessed.E and F,Western blot analysis of $\mathrm{Y}-\mathrm{H} 2 \mathrm{AX}, \mathrm{RPA}$ and $\mathrm{KU70}$ of A2780 cells in the presence of BD $(0.113 \mu \mathrm{g} / \mathrm{ml})$, afatinib $(0.885 \mu \mathrm{g} / \mathrm{ml})$, or the combination of $\mathrm{BD}(0.113 \mu \mathrm{g} / \mathrm{ml})$ and afatinib $(0.885 \mu \mathrm{g} / \mathrm{ml})$, and CP70 cells in the presence of BD $(0.073 \mu \mathrm{g} / \mathrm{ml})$, afatinib $(0.620 \mu \mathrm{g} / \mathrm{ml})$, or the combination of BD $(0.073 \mu \mathrm{g} / \mathrm{ml})$ and afatinib $(0.620 \mu \mathrm{g} / \mathrm{ml})$ for 48 hours. GAPDH was used as a loading control. Statistical significance was analysed using unpaired student's two-tailed t-tests. (ns, not significant, ${ }^{\star} p<0.05,{ }^{\star \star} p<0.01,{ }^{\star \star \star} p<$ 0.001).

\section{Supplementary Files}

This is a list of supplementary files associated with this preprint. Click to download.

- Supportinginformation.docx 